\title{
The Evolution of Staging of Cutaneous Squamous Cell Carcinomas: A Structured Review
}

\author{
${ }^{1}$ Mina N Le, ${ }^{2}$ Erica Lee, ${ }^{3}$ Bhuvanesh Singh
}

\begin{abstract}
Among non-melanoma skin cancers, cutaneous squamous cell carcinoma entails the highest morbidity and mortality, and yet there is little guidance on how to identify the subset of cutaneous squamous cell carcinomas that behave aggressively. The staging of non-melanoma skin cancers is meant to provide this guidance, by dividing patients into groups for which survival differs between groups, is similar within each group, and consistently decreases with each increasing stage group. In the present review, we explore the history of how the staging of nonmelanoma skin cancers, focusing on cutaneous squamous cell carcinomas, has evolved over time. We describe the common criticisms leveled at the American Joint Committee on Cancer (AJCC) staging rubric. We discuss alternative staging systems that have recently been proposed, and how they have stood up to validation. Finally, we preview the AJCC staging changes that will go into effect next year and lay out some future directions for the improvement of skin cancer staging.
\end{abstract}

Keywords: Cutaneous squamous cell carcinoma, Non-melanoma skin cancer, Prognostic factors, TNM staging.

How to cite this article: Le MN, Lee E, Singh B. The Evolution of Staging of Cutaneous Squamous Cell Carcinomas: A Structured Review. Int J Head Neck Surg 2017;8(2):57-63.

Source of support: Nil

Conflict of interest: None

\section{INTRODUCTION}

Nonmelanoma skin cancers (NMSCs), which include basal and squamous cell carcinomas (SCC), are the most common type of cancer worldwide. The incidence is rising 3 to $8 \%$ per year, in large part due to the increasing life expectancy of the world population. ${ }^{1}$ Among the types of NMSC, cutaneous squamous cell carcinoma

\footnotetext{
${ }^{1}$ Assistant Professor, ${ }^{2}$ Associate Director, ${ }^{3}$ Director and Surgeon

${ }^{1}$ UM Miller School of Medicine, University of Miami, Florida USA

${ }^{2}$ Mohs Micrographic and Dermatologic Surgery, Memorial Sloan Kettering Cancer Center, New York, USA

${ }^{3}$ Laboratory of Epithelial Cancer Biology; Head and Neck Service, Memorial Sloan Kettering Cancer Center, New York USA

Corresponding Author: Mina N Le, West Palm Beach VA Medical Center, 7305 N. Military Trail, Riviera Beach, Florida 33410, USA, Phone: 561422-6838, e-mail: mina.le@va.gov
}

(cSCC) entails the greatest morbidity and mortality: It claims 2,500 lives per year in the United States and thus accounts for $20 \%$ of deaths from skin cancer. ${ }^{2}$ It remains a challenge to identify the subset of cases of CSCC that behave aggressively. Few studies have assessed the many tumor and host variables that affect outcome in NMSCs. ${ }^{2}$ A better understanding of prognostic factors in NMSC, reflected in an updated staging system, would ensure that high-risk patients are targeted early for more aggressive treatment. In contrast to other cancers, most cases of NMSC are treated outside of tertiary care centers and there are no centralized databases that track treatment and outcome data. ${ }^{3}$

The staging of cancer is an invaluable tool for counseling patients, choosing the most appropriate therapy, and stratifying patients for clinical trials. The classic definition of a cancer staging system is that it groups cancer characteristics for which patient survival (1) differs between groups (distinctiveness), (2) is similar within a group (homogeneity), and (3) consistently decreases with increasing stage group (monotonicity). ${ }^{4}$ Since 1977, when the American Joint Committee on Cancer (AJCC) published the first edition of its Cancer Staging Manual, its tumor-node-metastasis (TNM) classification has been the benchmark by which all malignancies have been staged. This system is based on the concept that the prognosis of a cancer declines as the tumor advances from local disease to regional nodal involvement and finally to distant metastasis. Tumor-node-metastasis staging considers mainly anatomic parameters, and occasionally histopathologic factors, in assigning a stage. A structured review of the literature was conducted to define the evolution of staging of NMSCs, focusing on SCCs.

\section{MATERIALS AND METHODS}

PubMed was searched for titles containing "staging," "cutaneous," and "carcinoma" or "carcinomas"; titles containing "staging" and "skin cancer"; and titles containing "staging" and "squamous cell carcinoma." Articles not primarily pertinent to the staging of cutaneous malignancies were excluded (Table 1). Given that the seventh and current edition of the AJCC Cancer Staging Manual was released in 2009, articles from before 2009 proposing revisions to the AJCC staging system were excluded. Access to the first through sixth editions of the AJCC Cancer 


\begin{tabular}{cl}
\hline \multicolumn{2}{c}{ Table 1: Inclusion and exclusion criteria } \\
\hline Inclusion criteria & Exclusion criteria \\
\hline $\begin{array}{l}\text { PubMed search for titles } \\
\text { containing: }\end{array}$ & Articles on non-cutaneous \\
"staging" + "cutaneous" + & malignancies \\
"carcinoma" & Articles focusing on only a \\
"staging" + "cutaneous" + & subset of patients, such as \\
"carcinomas" & Articles focusing on sentinel \\
"staging" + "skin cancer" & node biopsy \\
or "staging" + "squamous cell & Articles from before 2009 \\
carcinoma" & proposing revisions to the \\
& AJCC staging system \\
\hline
\end{tabular}

Staging Manual was achieved by going to cancerstaging. org and clicking on Desk References.

\section{RESULTS}

A total of 12 articles satisfied the inclusion and exclusion criteria and form the backbone of this review.

\section{Tumor-Node-Metastasis Staging: The Early Years}

In the original 1977 version of the AJCC manual, NMSCs were given one of four $\mathrm{T}$ classifications based on their extent of local spread (Table 2). ${ }^{5}$ Tumors limited to the epidermis and not exceeding $2 \mathrm{~cm}$ in diameter were called T1. Tumors wider than $2 \mathrm{~cm}$ but not exceeding $5 \mathrm{~cm}$, or those with minimal invasion of the dermis, were called T2. Tumors wider than $5 \mathrm{~cm}$, or those deeply invading the dermis, were called T3. Tumors involving cartilage, muscle, or bone were called T4. Next, all NMSCs were assigned an $\mathrm{N}$ classification based on their extent of regional nodal spread. Finally, each tumor was called M0 if there was no distant metastasis and otherwise labeled M1. In this first edition of the TNM system, no overall stage classification (I-IV) was assigned to NMSCs. Clinicians were advised to record the grade of cSCCs as well differentiated (G1), moderately differentiated (G2), poorly differentiated (G3), or very poorly differentiated (G4). ${ }^{5}$

Over the ensuing decades, the AJCC's TNM staging system was updated half a dozen times as the prognostication of NMSCs evolved. In their second edition in 1983, $\mathrm{T}$ staging remained the same, but the $\mathrm{N}$ categories were reconfigured: N1 indicated mobile ipsilateral nodes, N2 indicated mobile contralateral or bilateral nodes, and N3 indicated fixed nodes. At this time, the first-stage groupings were created: Stage I for localized disease, stage II for regional metastatic disease, and stage III if distant metastases were present. ${ }^{6}$

The third edition in 1988 brought further change: This was the first year that the AJCC's staging system was designed to be perfectly identical with the staging system of the Union Internationale Contre le Cancer, the multinational cooperative group based in Switzerland, so that there was now a single TNM system used worldwide. ${ }^{7}$ For the first time, SCCs of the eyelid, vulva, and penis were relegated to separate staging paradigms. For the remaining cutaneous malignancies, the T staging was modified so that extent of dermal invasion was no longer a consideration, but only the maximal tumor diameter distinguished T1, T2, and T3. The cutoffs between these groups remained 2 and $5 \mathrm{~cm}$. N staging was now simplified to N0 vs N1, and the stage groupings were amended (Table 2). ${ }^{7}$ This version of the NMSC staging system remained the same in AJCC's fourth edition in $1992,{ }^{8}$ in the fifth edition in $1997,{ }^{9}$ and in the sixth edition in $2002 .^{10}$

\section{Tumor-node-metastasis Staging: The Present System}

Prior to publishing the seventh edition of its Cancer Staging Manual in 2009, the AJCC convened an NMSC staging committee under the direction of Dr Arthur Sober. This committee was charged with revamping the staging of NMSCs so that, for the first time in history, it would be truly evidence-based. To this end, they eliminated the NMSC umbrella classification, which had previously encompassed 82 tumor types, and replaced it with a staging system specifically aimed at cSCC. Merkel cell carcinoma, on account of its uniquely aggressive behavior, was removed to its own staging system.

The present definition of a T1 cSCC is that it does not exceed $2 \mathrm{~cm}$ in greatest diameter and it possesses fewer than two high-risk features. High-risk features are defined as follows: Depth exceeding $2 \mathrm{~mm}$; Clark level IV or V; perineural invasion; location on the ear or on the nonglabrous (i.e., hair-bearing) lip (recent literature is inconsistent when alluding to the inclusion of "nonglabrous lip" among the high-risk T factors in the seventh edition of AJCC staging. "Nonglabrous lip" is often mistranslated as "non-hair-bearing lip" or "vermilion lip." The word glabrous derives from the Latin glaber, meaning smooth or hairless, and therefore, the nonglabrous lip is in fact the nonhairless lip, i.e., the hair-bearing lip, not the vermilion); and poorly differentiated or undifferentiated grade. A T2 cSCC either exceeds $2 \mathrm{~cm}$ in greatest diameter, or has more than one high-risk feature. A T3 cSCC is one that invades the maxilla, mandible, orbit, or temporal bone, and a T4 cSCC either invades the skeleton elsewhere or exhibits perineural invasion at the skull base.

Given that most cSCCs occur on the head and neck, the $\mathrm{N}$ classifications for cSCC were revised to coincide exactly with the N staging of head and neck mucosal cancer, and the overall stage groupings were revised (Table 2).

Even though the present staging rubric is more stringently evidence-based, it has garnered its share of criticisms. ${ }^{3,11-14}$ The various subtypes of cSCC, from less aggressive histologies like verrucous carcinoma to more 
The Evolution of Staging of cSCCs: A Structured Review

Table 2: American joint committee on cancer staging of nonmelanoma skin cancers, first through seventh editions

\begin{tabular}{ll}
\hline $\begin{array}{l}\text { American joint committee on } \\
\text { cancer } 1^{\text {st }} \text { edition }\end{array}$ & $\begin{array}{l}\text { American joint committee on } \\
\text { cancer } 2^{\text {nd }} \text { edition }\end{array}$ \\
\hline T0 No primary tumor present & T0 No primary tumor present \\
T1 Tumor $2 \mathrm{~cm}$ or less in its & $\begin{array}{l}\text { T1 Tumor } 2 \mathrm{~cm} \text { or less in its } \\
\text { largest dimension, strictly }\end{array}$ \\
largest dimension, strictly & superficial or exophytic \\
superficial or exophytic & T2 Tumor more than $2 \mathrm{~cm}$ \\
T2 Tumor more than $2 \mathrm{~cm}$ & but not more than $5 \mathrm{~cm}$ in \\
but not more than $5 \mathrm{~cm}$ in & its largest dimension or with \\
its largest dimension or with & minimal infiltration of the \\
minimal infiltration of the dermis, & dermis, irrespective of size \\
irrespective of size & T3 Tumor more than $5 \mathrm{~cm}$ in \\
T3 Tumor more than $5 \mathrm{~cm}$ in & its largest dimension or with \\
its largest dimensions or with & deep infiltration of the dermis, \\
deep infiltration of the dermis, & irrespective of size \\
irrespective of size & T4 Tumor involving other \\
T4 Tumor involving other & structures such as cartilage, \\
structures such as cartilage, & muscle, or bone \\
muscle, or bone &
\end{tabular}

American joint committee on American joint committee on cancer $3^{\text {rd }}-6^{\text {th }}$ edition cancer $7^{\text {th }}$ edition

TO No evidence of primary T0 No evidence of primary tumor tumor Tis Carcinoma in situ

Tis Carcinoma in situ

T1 Tumor $2 \mathrm{~cm}$ or less in greatest dimension

T2 Tumor more than $2 \mathrm{~cm}$ but not more than $5 \mathrm{~cm}$ in greatest dimension

T3 Tumor more than $5 \mathrm{~cm}$ in greatest dimension

T4 Tumor invades deep extradermal structures (i.e., cartilage, skeletal muscle or bone)

T1 Tumor $2 \mathrm{~cm}$ or less in greatest dimension with fewer than 2 highrisk features*

T2 Tumor more than $2 \mathrm{~cm}$ in greatest dimension with or without one additional high-risk features*, or any size with more than 2 highrisk features*

T3 Tumor with invasion of maxilla, mandible, orbit, or temporal bone

T4 Tumor with invasion of skeleton (axial or appendicular) or perineural invasion of skull base *Depth (>2 mm thickness, Clark level IV or V); perineural invasion; location (ear, nonglabrous lip); differentiation (poorly differentiated or undifferentiated)

\begin{tabular}{|c|c|c|c|c|c|c|c|c|c|}
\hline $\begin{array}{l}\text { N0 No clinically positive nodes } \\
\text { N1 Single clinically positive } \\
\text { homolateral node less than } 3 \mathrm{~cm} \\
\text { in diameter } \\
\text { N2a Single clinically positive } \\
\text { homolateral node } 3 \text { to } 6 \mathrm{~cm} \text { in } \\
\text { diameter } \\
\text { N2b Multiple clinically positive } \\
\text { homolateral nodes, none over } \\
6 \mathrm{~cm} \text { in diameter } \\
\text { N3a Clinically positive } \\
\text { homolateral node(s), over } 6 \mathrm{~cm} \text { in } \\
\text { diameter } \\
\text { N3b Bilateral clinically positive } \\
\text { nodes } \\
\text { N3c Contralateral clinically } \\
\text { positive node(s) only }\end{array}$ & $\begin{array}{l}\text { N0 No evidence or regional } \\
\text { lymph node involvement } \\
\text { N1 Evidence of involvement } \\
\text { of movable homolateral } \\
\text { regional lymph nodes } \\
\text { N2 Evidence of involvement } \\
\text { of movable contralateral or } \\
\text { bilateral regional lymph nodes } \\
\text { N3 Evidence of involvement } \\
\text { of fixed regional lymph nodes }\end{array}$ & \multicolumn{4}{|c|}{$\begin{array}{l}\text { N0 No regional lymph node } \\
\text { metastasis } \\
\text { N1 Regional lymph node } \\
\text { metastasis }\end{array}$} & \multicolumn{4}{|c|}{$\begin{array}{l}\text { N0 No regional lymph node } \\
\text { metastasis } \\
\text { N1 Metastasis in single ipsilateral } \\
\text { lymph node, } 3 \mathrm{~cm} \text { or less in } \\
\text { greatest dimension } \\
\text { N2a Metastasis in single } \\
\text { eipsilateral lymph node, more than } \\
3 \mathrm{~cm} \text { but not more than } 6 \mathrm{~cm} \text { in } \\
\text { greatest dimension } \\
\text { N2b Metastasis in multiple } \\
\text { eipsilateral lymph nodes, none } \\
\text { over } 6 \mathrm{~cm} \text { in greatest dimension } \\
\text { N2c Metastasis in bilateral or } \\
\text { contralateral lymph nodes, none } \\
\text { over } 6 \mathrm{~cm} \text { in greatest dimension } \\
\text { N3 Metastasis in lymph node, over } \\
6 \mathrm{~cm} \text { in greatest dimension }\end{array}$} \\
\hline $\begin{array}{l}\text { M0 No (known) distant } \\
\text { metastasis }\end{array}$ & $\begin{array}{l}\text { M0 No (known) distant } \\
\text { metastasis }\end{array}$ & \multicolumn{4}{|c|}{ M0 No distant metastasis } & \multicolumn{4}{|c|}{ M0 No distant metastasis } \\
\hline M1 Distant metastasis present & M1 Distant metastasis present & \multicolumn{4}{|c|}{ M1 Distant metastasis } & \multicolumn{4}{|c|}{ M1 Present distant metastasis } \\
\hline \multirow[t]{9}{*}{$\begin{array}{l}\text { No stage grouping is } \\
\text { recommended at this time }\end{array}$} & $\begin{array}{l}\text { No stage grouping is } \\
\text { recommended at this time. At } \\
\text { the present time stage might } \\
\text { be recorded as follows: }\end{array}$ & 0 & Tis & No & M0 & 0 & Tis & N0 & M0 \\
\hline & I Localized T1 & I & $\mathrm{T} 1$ & No & M0 & I & $\mathrm{T} 1$ & No & M0 \\
\hline & II Regional nodal involvement & II & $\mathrm{T} 2$ & No & M0 & II & $\mathrm{T} 2$ & No & M0 \\
\hline & III Distant metastases & & T3 & No & MO & III & T3 & $\mathrm{N} 0$ or $\mathrm{N} 1$ & M0 \\
\hline & & III & $\mathrm{T} 4$ & No & MO & & $\mathrm{T} 1$ or $\mathrm{T} 2$ & N1 & M0 \\
\hline & & & Any $\mathrm{T}$ & N1 & M0 & IV & $\mathrm{T} 1,2$, or 3 & N2 & M0 \\
\hline & & IV & Any $T$ & Any $\mathrm{N}$ & M1 & & Any $T$ & N3 & M0 \\
\hline & & & & & & & $\mathrm{T} 4$ & Any $\mathrm{N}$ & MO \\
\hline & & & & & & & Any $\mathrm{T}$ & Any $\mathrm{N}$ & M1 \\
\hline
\end{tabular}

aggressive ones like spindle-cell carcinoma, are not distinguished. High-risk anatomic sites, such as the central face, temple, preauricular skin, and dorsal hands and feet are not mentioned. ${ }^{11}$ Whether a patient is immunosuppressed, or whether her tumor arises in a scar, burn, sinus tract, or site of chronic inflammation, is not recorded. ${ }^{11}$
Recurrent tumors are not considered separately. Many cSCCs never arrive at a final depth measurement, either because no residual tumor remains after initial biopsy, or because the chosen treatment modality is Mohs surgery, which focuses on surgical margins and often does not evaluate the excised tumor depth. Extranodal 
Table 3: Alternative T staging for cSCCs

\begin{tabular}{|c|c|c|}
\hline American joint committee on cancer $7^{\text {th }}$ edition & International union against cancer (UICC) & Brigham and Women's Hospital \\
\hline $\begin{array}{l}\text { T0 No evidence of primary tumor } \\
\text { Tis Carcinoma in situ } \\
\text { T1 Tumor } 2 \mathrm{~cm} \text { or less in greatest dimension with } \\
\text { fewer than } 2 \text { high-risk features* } \\
\text { T2 Tumor more than } 2 \mathrm{~cm} \text { in greatest dimension } \\
\text { with or without one additional high-risk feature*, } \\
\text { or any size with more than } 2 \text { high-risk features* } \\
\text { T3 Tumor with invasion of maxilla, mandible, } \\
\text { orbit, or temporal bone } \\
\text { T4 Tumor with invasion of skeleton (axial or } \\
\text { appendicular) or perineural invasion of skull base } \\
\text { *Depth (>2 mm thickness, Clark level IV or } \\
\text { V); perineural invasion; location (ear, nongla } \\
\text { brouslip); differentiation (poorly differentiated or } \\
\text { undifferentiated) }\end{array}$ & $\begin{array}{l}\text { T0 No evidence of primary tumor } \\
\text { Tis Carcinoma in situ } \\
\text { T1 Tumor } 2 \mathrm{~cm} \text { or less in greatest } \\
\text { dimension } \\
\text { T2 Tumor more than } 2 \mathrm{~cm} \text { in greatest } \\
\text { dimension } \\
\text { T3 Tumor with invasion of deep } \\
\text { structures such as muscle, cartilage, } \\
\text { bone (excluding axial skeleton), orbit } \\
\text { T4 Tumor with invasion of axial skeleton } \\
\text { or direct perineural invasion of skull base }\end{array}$ & $\begin{array}{l}\text { T0 Carcinoma in situ } \\
\text { T1 Tumor with } 0 \text { high-risk features* } \\
\text { T2a Tumor with } 1 \text { high-risk feature* } \\
\text { T2b Tumor with } 2-3 \text { high-risk features* } \\
\text { T3 Tumor with } 4 \text { high-risk features or } \\
\text { bone invasion } \\
\text { *Tumor or diameter } 2 \mathrm{~cm} \text { or greater; } \\
\text { poorly differentiated histology, } \\
\text { perineural invasion at least } 0.1 \mathrm{~mm} \text {; } \\
\text { tumor invasion beyond fat (excluding } \\
\text { bone invasion which automatically } \\
\text { upgrades tumor to BWH stage T3) }\end{array}$ \\
\hline
\end{tabular}

spread and micrometastases are not addressed. Finally, it seems illogical that appendicular bone invasion should automatically merit T4 status while facial bone invasion is only $\mathrm{T} 3 .^{11}$

\section{Alternative T Staging for Cutaneous Squamous Cell Carcinoma}

In light of these concerns with AJCC staging, JambusariaPahlajani et $\mathrm{al}^{15}$ set out to critically evaluate the performance of the current staging system on a retrospective cohort of 256 primary N0M0 cSCCs chosen to have at least one high-risk factor from among the following: Perineural or lymphovascular invasion, poorly differentiated histology, depth beyond subcutaneous fat, diameter at least $2 \mathrm{~cm}$, location on the ear, or location on the lip. Eighty percent were treated with primary surgery, and $11 \%$ received postoperative radiation. During a median follow-up time of 44 months, the local recurrence rate was $8 \%$, the nodal metastasis rate was $10 \%$, and the disease-specific death rate was $5 \%$. By the AJCC rubric, $54 \%$ of the cohorts were $\mathrm{T} 1$ and $44 \%$ were $\mathrm{T} 2$. As expected, given this distribution, $87 \%$ of incidences of recurrence, metastasis, or death occurred in the T2 group. The AJCC staging system did not perform well because so few tumors were $\mathrm{T} 3$ or $\mathrm{T} 4$, leaving a large $\mathrm{T} 2$ group which was widely heterogeneous in terms of outcomes.

Upon multivariate analysis of independent prognostic predictors of local recurrence, nodal metastasis, diseasespecific mortality, and all-cause mortality, JambusariaPahlajani et $\mathrm{l}^{15}$ proposed an alternative $\mathrm{T}$ staging system which would better stratify the T2 group. This system is based on the risk factors which they found to be strongly predictive of at least two of the above negative outcomes: Tumor diameter $2 \mathrm{~cm}$ or greater, poorly differentiated histology, perineural invasion, and invasion past subcutaneous fat. Stage T1 tumors have none of these four risk factors, T2a tumors have a single risk factor, $\mathrm{T} 2 \mathrm{~b}$ tumors have two to three risk factors, and T3 tumors have all four risk factors or bone invasion (AJCC T3/T4). By this alternative staging system, $52 \%$ of the cohorts fell into $\mathrm{T} 1$ and had local recurrence rates of $14 \%$, nodal metastasis rates of $4 \%$, and $0 \%$ disease-specific death; $26 \%$ of the cohorts were rebranded T2a and had local recurrence rates of $29 \%$, nodal metastasis rates of $12 \%$, and $0 \%$ disease-specific death; $19 \%$ of the cohorts were restaged $\mathrm{T} 2 \mathrm{~b}$ and had local recurrence rates of $43 \%$, nodal metastasis rates of $72 \%$, and $83 \%$ disease-specific death. Thus, the alternative staging system was able to reassign cSCCs to $\mathrm{T}$ stage groups with more distinct risks of negative outcomes when compared with AJCC staging (Table 3).

The Brigham and Women's Hospital (BWH) T staging system was subsequently validated on a series of 1,818 primary cSCCs, and again the AJCC T1/T2 outcomes were widely heterogeneous, while T3 and T4 lost their meaning as those groups were so small. Again the BWH stages were more distinctive, properly concentrating the majority of poor outcomes among T2b and T3. ${ }^{16}$

\section{Alternative N Staging for Cutaneous Squamous Cell Carcinoma}

As with T staging, the N staging of cSCC has stood to gain from a more rigorous grounding in evidence. Although fewer than $5 \%$ of cSCC metastasize, regional metastasis drops the 5-year disease-free survival rate to 70 to $75 \%$ even with combined modality treatment. ${ }^{17}$ When they metastasize, head and neck cSCC spread initially to the parotid and then to the neck. ${ }^{17} \mathrm{O}^{\prime}$ Brien et $\mathrm{al}^{18}$ hypothesized that parotid metastases and neck metastases would have independent prognostic significance. To test this, they prospectively collected 87 patients with cSCC involving the parotid gland and staged them according to the following system: P1 for a parotid node up to $3 \mathrm{~cm}$, P2 for one parotid node between 3 and $6 \mathrm{~cm}$ or multiple parotid nodes, P3 for a parotid node larger than $6 \mathrm{~cm}$ or 


\begin{tabular}{llll}
\hline \multicolumn{3}{c}{ Table 4: Alternative N staging for cSCCs } \\
\hline American joint committee on cancer $7^{\text {th }}$ edition & O'Brien & N1S3 \\
\hline N0 No regional lymph node metastasis & P1 Metastatic parotid node up to $3 \mathrm{~cm}$ in diameter & I Single lymph node \\
N1 Metastasis in single ipsilateral lymph node, & P2 Metastatic parotid node greater than $3 \mathrm{~cm}$ but not & measuring up to $3 \mathrm{~cm}$ \\
$3 \mathrm{~cm}$ or less in greatest dimension & more than $6 \mathrm{~cm}$ in diameter, or multiple parotid nodes & II Single lymph node \\
N2a Metastasis in single ipsilateral lymph node, & P3 Metastatic parotid node more than $6 \mathrm{~cm}$ in & measuring greater than \\
more than $3 \mathrm{~cm}$ but not more than $6 \mathrm{~cm}$ in & diameter or disease involving facial nerve or skull & $3 \mathrm{~cm}$, or multiple lymph \\
greatest dimension & base & nodes measuring up to \\
N2b Metastasis in multiple ipsilateral lymph nodes, & N0 No clinical neck disease & $3 \mathrm{~cm}$ \\
none over $6 \mathrm{~cm}$ in greatest dimension & N1 Single ipsilateral neck node up to $3 \mathrm{~cm}$ diameter & III Multiple lymph nodes \\
N2c Metastasis in bilateral or contralateral lymph & N2 Single ipsilateral neck node more than $3 \mathrm{~cm}$ in & measuring greater than \\
nodes, none over $6 \mathrm{~cm}$ in greatest dimension & diameter, or multiple neck nodes, or contralateral & $3 \mathrm{~cm}$ \\
N3 Metastasis in lymph node, over $6 \mathrm{~cm}$ in & nodes & & \\
greatest dimension & &
\end{tabular}

for involvement of the facial nerve or skull base, N1 for a neck node up to $3 \mathrm{~cm}$, and N2 for any more extensive neck disease. On multivariate analysis, they found that P2 or P3 stage predicted for reduced control in the parotid, and that N2 predicted for decreased survival. O'Brien's system was then tested retrospectively on a group of 322 patients from six institutions, both Australian and North American. His new staging rubric was validated to some degree, as multivariate analysis showed that clinical P3 stage and pathologic N1/N2 stage independently influenced survival. Once again, however, there was no evidence that having three distinct $\mathrm{P}$ stages and three $\mathrm{N}$ stages was useful (Table 4). ${ }^{19}$

Building upon O'Brien's work, Forest et $\mathrm{al}^{20}$ proposed a simplified N staging system for cSCC called N1S3, which counts the parotid as a basin of the neck. Patients with a single node $3 \mathrm{~cm}$ or smaller are N1S3 stage I; a single node greater than $3 \mathrm{~cm}$ or multiple nodes up to $3 \mathrm{~cm}$ qualify as N1S3 stage II; and patients with multiple nodes greater than $3 \mathrm{~cm}$ are N1S3 stage III. This system successfully stratifies those three groups of patients by locoregional control, by disease-specific survival, and by overall survival, all with a $\mathrm{p}$-value $<0.001$. The authors were able to validate this on an external patient cohort as well. Their study also had implications for treatment: By showing that N1S3 stage I patients have a 5 -year disease-specific survival of $90 \%$, they could recommend that these patients be treated with parotidectomy and selective neck dissection alone and be spared the morbidity of adjuvant radiation, if there is no extracapsular spread.

The same group directly compared N1S3 N staging with AJCC N staging, using 603 patients from two prospective databases, and found the N1S3 system superior in terms of patient distribution, stratification, and parsimony. For instance, three of the AJCC groups (N2a, N2c, and N3) together contained less than $10 \%$ of all patients, whereas the smallest N1S3 group (III) contained 14\%. The Kaplan-Meier disease-specific survival curves, which overlap each other in AJCC, separate widely in
N1S3. The authors argued that accurate N staging is of particular importance in cSCC because nodal metastases often present late and it can be impossible to know which cutaneous primary led to nodal spread; furthermore, once a patient falls among the $5 \%$ of cSCC patients who develop nodal metastases, primary tumor factors no longer play as much of a role in the prognosis. ${ }^{21}$

\section{Tumor-Node-Metastasis Staging: Next Year's Update}

The eighth edition of the AJCC staging system will be implemented on January 1, 2018. One of the most prominent changes is that basal cell carcinomas, which had been included in the same AJCC staging system as CSCC from 1977 until 2009 until they were excluded starting in the seventh edition, have been brought under the same staging system as cSCC once more, along with all other NMSCs other than Merkel cell carcinoma. Conversely, all NMSCs occurring outside the head and neck have been excluded from the eighth-edition rubric and will fall under no AJCC staging system at all. The T staging criteria have been simplified, and the $\mathrm{N}$ staging criteria have been updated to reflect the poor prognosis conferred by extranodal extension (Table 5).

\section{DISCUSSION}

Despite the widespread prevalence and rising incidence of NMSC, staging in this disease remains suboptimal, largely because of a lack of multivariate analysis of the prognostic influence of tumor, host, and treatment factors. The present AJCC staging system for NMSC, effective as of 2010, was more evidence-based than prior systems, and the upcoming eighth edition improves upon it still further. However, there is still no consideration for immunosuppression, or for other high-risk anatomic locations as defined in the National comprehensive cancer network (NCCN) guidelines, or for staging basal cell carcinoma separately. Ample room remains for prospectively designed multicenter studies of prognostic factors 
Table 5: American joint committee on cancer staging of nonmelanoma skin cancers, seventh versus eighth editions

\begin{tabular}{|c|c|c|c|c|c|c|c|}
\hline \multirow{10}{*}{\multicolumn{4}{|c|}{$\begin{array}{l}\text { American joint committee on cancer } 7^{\text {th }} \text { edition } \\
\text { T0 No evidence of primary tumor } \\
\text { Tis Carcinoma in situ } \\
\text { T1 Tumor } 2 \mathrm{~cm} \text { or less in greatest dimension with fewer than } \\
2 \text { high-risk features* } \\
\text { T2 Tumor more than } 2 \mathrm{~cm} \text { in greatest dimension with or without } \\
\text { one additional high-risk feature*, or any size with more than } 2 \text { high- } \\
\text { risk features* } \\
\text { T3 Tumor with invasion of maxilla, mandible, orbit, or temporal } \\
\text { bone } \\
\text { T4 Tumor with invasion of skeleton (axial or appendicular) or } \\
\text { perineural invasion of skull base } \\
\text { *Depth (>2 mm thickness, Clark level IV or V); perineural invasion; } \\
\text { location (ear, nonglabrous lip); differentiation (poorly differentiated } \\
\text { or undifferentiated) }\end{array}$}} & \multicolumn{4}{|c|}{ American joint committee on cancer $8^{\text {th }}$ edition } \\
\hline & & & & \multicolumn{4}{|c|}{ Tx Primary tumor cannot be identified } \\
\hline & & & & \multicolumn{4}{|c|}{ Tis Carcinoma in situ } \\
\hline & & & & \multicolumn{4}{|c|}{ T1 Tumor smaller than $2 \mathrm{~cm}$ in greatest dimension } \\
\hline & & & & \multicolumn{4}{|c|}{$\begin{array}{l}\text { T2 Tumor } 2 \mathrm{~cm} \text { or larger, but smaller than } 4 \mathrm{~cm} \text { in greatest } \\
\text { dimension }\end{array}$} \\
\hline & & & & \multicolumn{4}{|c|}{$\begin{array}{l}\text { T3 Tumor } 4 \mathrm{~cm} \text { or larger in maximum dimension, or minor bone } \\
\text { erosion, or perineural invasion, or deep invasion (beyond fat or }\end{array}$} \\
\hline & & & & \multirow{2}{*}{\multicolumn{4}{|c|}{$\begin{array}{l}>6 \mathrm{~mm} \text { ) } \\
\text { T4a Tumor with gross invasion of cortical bone or marrow }\end{array}$}} \\
\hline & & & & & & & \\
\hline & & & & \multirow{2}{*}{\multicolumn{4}{|c|}{$\begin{array}{l}\text { T4b Tumor with skull base invasion or skull base foramen } \\
\text { involvement }\end{array}$}} \\
\hline & & & & & & & \\
\hline \multirow{6}{*}{\multicolumn{4}{|c|}{$\begin{array}{l}\text { N0 No regional lymph node metastasis } \\
\text { N1 Metastasis in single ipsilateral lymph node, } 3 \mathrm{~cm} \text { or less in } \\
\text { greatest dimension } \\
\text { N2a Metastasis in single ipsilateral lymph node, more than } 3 \mathrm{~cm} \\
\text { but not more than } 6 \mathrm{~cm} \text { in greatest dimension } \\
\text { N2b Metastasis in multiple ipsilateral lymph nodes, none over } 6 \mathrm{~cm} \\
\text { in greatest dimension } \\
\text { N2c Metastasis in bilateral or contralateral lymph nodes, none over } \\
6 \mathrm{~cm} \text { in greatest dimension } \\
\text { N3 Metastasis in lymph node over } 6 \mathrm{~cm} \text { in greatest dimension }\end{array}$}} & \multicolumn{4}{|c|}{ N0 No regional lymph node metastasis } \\
\hline & & & & \multirow{2}{*}{\multicolumn{4}{|c|}{$\begin{array}{l}\text { N1 Metastasis in single ipsilateral lymph node, } 3 \mathrm{~cm} \text { or smaller, } \\
\mathrm{ENE}(-) \\
\mathrm{N} 2 \text { a Metastasis in single ipsilateral lymph node larger than } 3 \mathrm{~cm} \\
\text { but not larger than } 6 \mathrm{~cm} \text {, ENE(-) }\end{array}$}} \\
\hline & & & & & & & \\
\hline & & & & \multicolumn{4}{|c|}{$\begin{array}{l}\text { N2b Metastasis in multiple ipsilateral lymph nodes, none larger } \\
\text { than } 6 \mathrm{~cm}, \operatorname{ENE}(-)\end{array}$} \\
\hline & & & & \multirow{2}{*}{\multicolumn{4}{|c|}{$\begin{array}{l}\text { N2c Metastasis in bilateral or contralateral lymph nodes, none } \\
\text { larger than } 6 \mathrm{~cm} \text {, ENE(-) } \\
\text { N3a Metastasis in a lymph node larger than } 6 \mathrm{~cm} \text { and } \mathrm{ENE}(-) \\
\text { N3b Metastasis in any lymph node(s) and } \mathrm{ENE}(+)\end{array}$}} \\
\hline & & & & & & & \\
\hline \multirow{2}{*}{\multicolumn{4}{|c|}{$\begin{array}{l}\text { M0 No distant metastasis } \\
\text { M1 Distant metastasis }\end{array}$}} & \multirow{2}{*}{\multicolumn{4}{|c|}{$\begin{array}{l}\text { M0 No distant metastasis } \\
\text { M1 Distant metastasis }\end{array}$}} \\
\hline & & & & & & & \\
\hline 0 & Tis & No & M0 & 0 & Tis & No & M0 \\
\hline 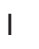 & $\mathrm{T} 1$ & No & M0 & I & $\mathrm{T} 1$ & No & MO \\
\hline$\|$ & $\mathrm{T} 2$ & No & MO & II & $\mathrm{T} 2$ & No & M0 \\
\hline \multirow[t]{2}{*}{ III } & T3 & N0 or N1 & M0 & \multirow[t]{2}{*}{ III } & T3 & N0 or N1 & MO \\
\hline & T1 or T2 & $\mathrm{N} 1$ & MO & & $\mathrm{T} 1$ or $\mathrm{T} 2$ & $\mathrm{~N} 1$ & MO \\
\hline \multirow[t]{4}{*}{ IV } & $\mathrm{T} 1,2$, or 3 & N2 & MO & \multirow[t]{4}{*}{ IV } & $\mathrm{T} 1,2$, or 3 & N2 & Mo \\
\hline & Any $\mathrm{T}$ & N3 & MO & & Any $T$ & N3 & MO \\
\hline & $\mathrm{T} 4$ & Any $N$ & MO & & $\mathrm{T} 4$ & Any $\mathrm{N}$ & MO \\
\hline & Any $T$ & Any $\mathrm{N}$ & M1 & & Any $\mathrm{T}$ & Any $\mathrm{N}$ & M1 \\
\hline
\end{tabular}

ENE: Extra nodal extension

in NMSC and for validation of new proposed staging systems in diverse patient cohorts. A more accurate staging of NMSC would guide clinicians in targeting high-risk patients for adjuvant therapy and clinical trials.

\section{REFERENCES}

1. Lardaro T, Shea SM, Sharfman W, Liégeois N, Sober AJ. Improvements in the staging of cutaneous squamous-cell carcinoma in the 7th edition of the AJCC Cancer Staging Manual. Ann Surg Oncol 2010 Aug;17(8):1979-1080.

2. Farasat S, Yu SS, Neel VA, Nehal KS, Lardaro T, Mihm MC, Byrd DR, Balch CM, Califano JA, Chuang AY, et al. A new American Joint Committee on Cancer staging system for cutaneous squamous cell carcinoma: creation and rationale for inclusion of tumor (T) characteristics. J Am Acad Dermatol 2011 Jun;64(6):1051-1059.

3. Miller SJ. Staging cutaneous squamous cell carcinoma. JAMA Dermatol 2013 Apr;149(4):472-474.

4. Clark JR, Rumcheva P, Veness MJ. Analysis and comparison of the 7th edition American Joint Committee on Cancer (AJCC) nodal staging system for metastatic cutaneous squamous cell carcinoma of the head and neck. Ann Surg Oncol 2012 Dec;19(13):4252-4258.

5. Beahrs, OH.; Carr, DT.; Rubin, P.; editors. Manual for staging of cancer 1977. Chicago (IL): American Joint Committee for Cancer Staging and End Results Reporting; 1977. Available from: cancerstaging.org.

6. Beahrs, OH.; Myers, MH.; editors. Manual for staging of cancer. 2nd ed. American Joint Committee on Cancer. Philadelphia (PA): J.B. Lippincott Company; 1983. Available from: cancerstaging.org.

7. Beahrs, OH.; Henson, DE.; Hutter, RVP.; Myers, MH.; editors. Manual for staging of cancer. 3rd ed. American Joint Committee on Cancer. Philadelphia (PA): J.B. Lippincott Company; 1988. Available from: cancerstaging.org.

8. Beahrs, OH.; Henson, DE.; Hutter, RVP.; Kennedy, BJ.; editors. Manual for staging of cancer. 4 th ed. American Joint Committee on Cancer. Philadelphia (PA): J.B. Lippincott Company; 1992. Available from: cancerstaging.org.

9. Fleming, ID.; Cooper, JS.; Henson, DE.; Hutter, RVP.; Kennedy, BJ.; Murphy, GP.; O'Sullivan, B.; Sobin, LH.; Yarbro, JW.; editors. AJCC cancer staging manual. 5th ed. Philadelphia (PA): Lippincott-Raven Publishers; 1997. Available from: cancerstaging.org. 
10. Greene, FL.; Page, DL.; Fleming, ID.; Fritz, AG.; Balch, CM.; Haller, DG.; Morrow, M.; editors. AJCC cancer staging manual. 6th ed. Philadelphia (PA): Lippincott Raven Publishers; 2002. Available from: cancerstaging.org.

11. Buethe D, Warner C, Miedler J, Cockerell CJ. Focus issue on squamous cell carcinoma: practical concerns regarding the 7th edition AJCC staging guidelines. J Skin Cancer 2011;2011:156391.

12. Warner CL, Cockerell CJ. The new seventh edition American Joint Committee on Cancer staging of cutaneous non-melanoma skin cancer: a critical review. Am J Clin Dermatol 2011 Jun;12(3):147-154.

13. Breuninger H. Seventh edition American Joint Committee on Cancer staging of cutaneous non-melanoma skin cancer. Am J Clin Dermatol 2011 Jun;12(3):155.

14. Breuninger $H$, Brantsch $K$, Eigentler T, Häfner HM. Comparison and evaluation of the current staging of cutaneous carcinomas. J Dtsch Dermatol Ges 2012 Aug;10(8): 579-586.

15. Jambusaria-Pahlajani A, Kanetsky PA, Karia PS, Hwang WT, Gelfand JM, Whalen FM, Elenitsas R, Xu X, Schmults CD. Evaluation of AJCC tumor staging for cutaneous squamous cell carcinoma and a proposed alternative tumor staging system. JAMA Dermatol 2013 Apr;149(4):402-410.

16. Karia PS, Jambusaria-Pahlajani A, Harrington DP, Murphy GF, Qureshi AA, Schmults CD. Evaluation of American Joint Committee on Cancer, international union against cancer, and Brigham and women's hospital tumor staging for cutaneous squamous cell carcinoma. J Clin Oncol 2014 Feb;32(4): 327-334.

17. Veness MJ, Morgan GJ, Palme CE, Gebski V. Surgery and adjuvant radiotherapy in patients with cutaneous head and neck squamous cell carcinoma metastatic to lymph nodes: combined treatment should be considered best practice. Laryngoscope 2005 May;115(5):870-875.

18. O'Brien CJ, McNeil EB, McMahon JD, Pathak I, Lauer CS, Jackson MA. Significance of clinical stage, extent of surgery, and pathological findings in metastatic cutaneous squamous cell carcinoma of the parotid gland. Head Neck 2002 May;24(5):417-422.

19. Andruchow JL, Veness MJ, Morgan GJ, Gao K, Clifford A, Shannon KF, Poulsen M, Kenny L, Palme CE, Gullane P, et al. Implications for clinical staging of metastatic cutaneous squamous carcinoma of the head and neck based on a multicenter study of treatment outcomes. Cancer 2006 Mar;106(5):1078-1083.

20. Forest VI, Clark JJ, Veness MJ, Milross C. N1S3: a revised staging system for head and neck cutaneous squamous cell carcinoma with lymph node metastases: results of 2 Australian Cancer Centers. Cancer 2010 Mar;116(5):1298-1304.

21. Clark JR, Rumcheva P, Veness MJ. Analysis and comparison of the 7th edition American Joint Committee on Cancer (AJCC) nodal staging system for metastatic cutaneous squamous cell carcinoma of the head and neck. Ann Surg Oncol 2012 Dec;19(13):4252-4258. 